\title{
TINGKAT KOGNISI ANAK INDONESIA BERUSIA 5,5-12,0 TAHUN: HASIL SEANUTS DI INDONESIA
}

\author{
Nurmeida S. Syarief', Basuki Budiman ${ }^{1.2}$, Sandjaja ${ }^{1,2}$ \\ 1 Persatuan Ahli Gizi Indonesia (PERSAGI) \\ 2Pusat Teknologi Terapan Kesehatan dan Epidemiologi Klinik \\ basukibudiman@yahoo.com
}

\begin{abstract}
ABSTRAK
Perkembangan kognisi atau karakteristik mental dicirikan dengan perkembangan persepsi, memori, imajinasi, daya pikir, kecerdasan. Artikel ini menyajikan hasil SEANUTS tentang tingkat kognisi anak berusia 5,5-12,0 tahun secara deskriptif. Partisipan sebanyak 1368 menggambarkan populasi nasional yang diambil secara acak jamak bertingkat (two stage randomized cluster sampling). Raven's Coloured Progressive Matrices (CPM) digunakan untuk mengukur tingkat kognisi anak. Kelompok anak terdiri 5,57,9 tahun dan 8,0-12,0 tahun. Tingkat kognisi disajikan menurut postur tubuh. Postur dinilai dari skor Z pada indeks TB/U. Tingkat kognisi di bawah rerata pada anak kelompok berusia 5,5-7,9 tahun antara 16,050,0 persen; dan kelompok berusia 8,0-12,0 tahun antara 25,7-69,6 persen. Secara keseluruhan, asosiasi antara kognisi dan postur tubuh tidak nyata pada anak berusia 5,5-7,9 tahun. Pada kelompok usia yang lebih tua tampak perbedaan yang signifikan baik di perkotaan maupun di perdesaan $(p<0,05)$. Namun demikian, hubungan itu diduga dipengaruhi oleh lingkungan tempat anak tumbuh termasuk stimulasi neuropsikologis dan status gizi baik mikro maupun makro.
\end{abstract}

Kata kunci: kognisi, postur, CPM, anak Indonesia

\section{ABSTRACT}

\section{COGNITIVE LEVEL OF CHILDREN 5.5-12.0 YEARS OLD: RESULT OF SEANUTS IN INDONESIA}

Cognitive or mental characteristic development includes development of perception, memory, imagination, intellectual skill and IQ. This article provides SEANUTS' result especially on mental development of school children (5.5-12.0 years old). A nationally representative number of 1368 children involved in this study. Two-stage randomized cluster sampling was implied for deriving required participants. Raven's Coloured Progressive Matrices (CPM) was administered to measure cognition. Posture was represented by HAZ score. Results showed that proportion of level cognition was below average in the 5.5-7.9 year age group and in the 8.0-12.0 year age group between 16.0-50.0 percent and 25.7-69.6 percent respectively. The association between cognition and posture at younger group was unclear while at older group, it seemed significantly different $(p<0.05)$ both in rural and urban. However, the significant association at lower cognition level were influenced by environment where chlidren grow including neuropsychological stimulation and nutritional status both micro- and macronutrient level.

Keywords: cognition, posture, CPM, Indonesian children

\section{PENDAHULUAN}

$\mathrm{P}$ erkembangan kognisi, disebut juga perkembangan karakteristik mental dicirikan antara lain dengan perkembangan persepsi, memori, imajinasi, daya pikir, kecerdasan. SEANUTS mengumpulkan data perkembangan kognisi anak yang berusia 5,5-12,0 tahun. ${ }^{1}$ Kelompok ini menurut Piaget terdiri dari periode perkembangan kognisi yaitu institutive thought (4-7,9 tahun) dan concrete operational (8-11 tahun). ${ }^{2}$
Keterlambatan perkembangan kognisi, terutama motorik halus, memori dan konsentrasi, umum dijumpai pada anak berusia pra sekolah dan usia sekolah (6-12 tahun). Di Bavaria, German sebesar 12,2 persen anak berusia masuk sekolah yang mengalami keterlambatan motorik halus dan sebesar 11,3 persen mengalami keterlambatan memori dan konsentrasi. Anak laki berisiko 3,2 kali daripada perempuan. ${ }^{3}$ Di Kenya anak yang berusia 6-9 tahun yang mengalami keterlambatan kognitif sebesar 24 setiap 1000 anak. Pada penelitian di Kenya ini dilaporkan faktor risiko keterlambatan 
neuropsikologik: antara lain ibu mempunyai anak lebih dari lima, umur ibu lebih dari 35 tahun. ${ }^{4}$

Beberapa penelitian yang dilaksanakan di Kanada, United Kingdom, Turki dan Indonesia dan dirancang randomized controlled trials (RCT) tentang efek suplementasi zat gizi besi pada bayi dan anak (0-9 tahun) terhadap perkembangan mental dan psikomotor telah di review Szajewska dkk. (2010)..$^{5}$ Hasilnya menunjukkan bahwa status anemia pada bayi dan anak mempengaruhi perkembangan psikomotor tetapi tidak terpengaruh perkembangan pada mental.

Lima tahun sebelumnya Sachdev dkk. (2006) melakukan review penelitian RCT dan kohor tentang pengaruh suplementasi zat gizi besi terhadap pertumbuhan fisik. Hasil menunjukkan bahwa suplementasi zat gizi besi tidak berpengaruh terhadap pertumbuhan fisik termasuk postur tubuh. ${ }^{6}$ Lucas dkk. (1998) meneliti pengaruh ketidakterpenuhi kebutuhan zat gizi pada bayi baru lahir dengan berat badan rendah (BBLR) terhadap kognisi anak tersebut pada usia sekitar delapan tahun. Jumlah bayi BBLR sebanyak 424 anak diberi perlakuan secara random tersamar pada waktu bayi dan pada usia 7,5-8 tahun (sebanyak 360 bayi yang hidup) diperiksa kognisinya. Perlakuan yang diberikan adalah salah satu dari dua macam yaitu (1) susu formula yang diperkaya zat gizi atau (2) suplementasi ASI dengan zat gizi. Pelakuan dilaksanakan selama satu bulan. Bayi BBLR yang menerima susu formula mencapai kognisi (kemampuan bahasa) lebih rendah (12.2 poin) dalam skala Weschler (WISC). ${ }^{7}$

Secara langsung dan tidak langsung, zat gizi makro dan _mikro berpengaruh terhadap perkembangan neuropsikologi termasuk motorik anak. Zat gizi makro yang dikaitkan dengan gangguan perkembangan fungsi otak adalah defisiensi energi protein dan asam lemak ${ }^{8,9}$ dan zat gizi mikro terutama zat gizi besi (Fe), Zinc (Zn) dan vitamin A . 10.11.12 Lebih dari dua dekade yang lalu, Udani (1992) telah memberi informasi bahwa penelitian eksperimen pada binatang dan pada anak di negara berkembang membuktikan kurang energi-protein masa kanak-kanak berdampak buruk pada perkembangan otak yaitu kerusakan dan kandungan jaringan, diferensiasi, mielinasi sel otak, jumlah dan transmisi sinap berkurang, serta disfungsi aktivitas dendrit. Kerusakan ini telah dijelaskan dengan data klinis, biokimia, histologi, magnetic resonance imaging (MRI). ${ }^{13}$

\section{METODE PENELITIAN}

SEANUTS (Southeast Asian Nutrition Survey) adalah penelitian status gizi anak berusia 0,5-12 tahun yang multisenter di empat negara. Disain, lokasi, jumlah dan cara perkrutan partisipan dalam penelitian ini telah dijelaskan secara rinci oleh Sandjaja, dkk (2013) dalam terbitan ini. ${ }^{1}$ Jumlah partisipan untuk analisis sebanyak 1368 anak berusia 5,512,0 tahun, yang terdiri dari 595 anak berusia 5,5-7,9 tahun dan 773 anak berusia 8,0-12,0 tahun. Pengelompokan ini didasarkan pada tahap perkembangan mental anak menurut Piaget. Menurut tempat tinggal, jumlah anak di perkotaan sebanyak 719 dan perdesaan 649 anak. Menurut jenis kelamin anak lelaki sebanyak 670 dan perempuan 698 anak.

Skala Weschler adalah salah satu cara mengukur kognisi melalui kemampuan intelektual (Intellectual Quotient, IQ) secara kuantitatif. Skala Weschler dikembangkan dari pengukuran Skala Binet.14 Pengukuran lain secara semi kuantitatif adalah Raven's Progressive Matrices (RPM). ${ }^{15}$ SEANUTS mencakup penelitian kognisi pada anak usia 612 tahun dengan cara RPM. RPM mengukur kemampuan kognisi anak melalui pemahaman non-verbal berdasarkan stimulus bentuk (figural) sehingga bebas aspek budaya (culture free). Metode ini banyak digunakan dalam penelitian karena metode ini tidak terkait dengan kemampuan verbal subyek seperti bahasa, membaca dan menulis. Metode ini dirancang untuk menilai (tes) kemampuan intelektual subyek berusia lima tahun atau lebih tua yang mengacu pada inteligensia umum. Perangkat penilaian dibedakan menurut kelompok umur yaitu (1) Standard Progresive Matrices (SPM); (2) Coloured Progressive Matrices (CPM); dan (3) Advanced Progresive Matrices (APM). CPM dirancang untuk menilai subyek berusia 5-12 tahun, atau subyek dewasa yang berkebutuhan khusus secara fisik dan mental. CPM terdiri dari BAB (set) A dan $B$ SPM dan 12 item yang disisipkan di antara kedua $B A B$ tersebut yang disebut $B A B A b$. Penilaian hasil dilakukan dengan skor antara 1100 , kemudian skor yang dihasilkan dibuat dalam lima tingkat kognisi menurut kelompok 
usia yang spesifik, yaitu: tinggi (superior, $\geq 90$ ), di atas rerata (65-89), rerata (35-64), di bawah rerata (20-34), dan rendah (<20).

Di samping mengukur kognisi, SEANUTS juga mengukur tinggi badan untuk menilai postur tubuh. Tinggi diukur dengan pengukur tinggi badan "Microtoise" dengan ketelitian 0,1 $\mathrm{cm}$. Postur tubuh dinilai dari skor $Z$ untuk tinggi badan menurut umur (skor $Z$ indeks TB/U). Anak dengan skor $Z$ indeks TB/U kurang dari tiga kali simpang baku $(-3,0 \mathrm{SD})$ dari median pertumbuhan $Z$ indeks $T B / U^{16}$, maka postur tubuhnya termasuk sangat pendek; jika antara 3 SD dan -2,0 SD disebut pendek dan yang skornya >-2SD disebut normal.

Data disajikan dalam grafik dan tabel yang distribusi nilainya diuji secara statistik dengan Chi square dan menggunakan perangkat lunak SPPS versi 17,0 .

\section{HASIL}

Pada Gambar 1 disajikan sebaran proporsi tingkat kognisi menurut postur tubuh anak di daerah perkotaan dan perdesaan. Proporsi tingkat kognisi adalah persen dari jumlah kasus tiap kategori kognisi terhadap jumlah anak di setiap klasifikasi postur. Pada kelompok anak berusia 5,5-7.9 tahun di perkotaan, ditemukan anak dengan postur pendek dan sangat pendek sebesar 25,1 persen, sedang di perdesaan sebesar 38,1 persen. Pada kelompok anak berusia 8,0-12 tahun ditemukan 27,9 dan 35,2 persen untuk perkotaan dan perdesaan.

Keragaman proporsi tingkat kognisi pada anak berusia 5,5-7,9 tahun menurut postur tubuh di perkotaan tidak berbeda, tetapi berbeda secara nyata $(p=0,033)$ di perdesaan. Tingkat kognisi yang berada di bawah rerata pada kelompok ini lebih dari separuh jumlah anak (Gambar 1 dan Tabel 1). Tingkat kognisi di bawah rerata dan rendah di perkotaan terdeteksi pada anak yang posturnya pendek, tetapi tidak ditemukan pada anak yang sangat pendek. Pada anak yang posturnya normal, proporsinya lebih kecil daripada anak yang pendek. Di perdesaan tingkat kognisi di bawah rerata ditemukan pada anak yang sangat pendek dan proporsinya semakin mengecil pada postur badan yang lebih tinggi. Postur sangat pendek di perkotaan ditemukan 3 anak $(0,98 \%)$, sedang di perdesaan sebanyak 20 anak $(6,94 \%)$.

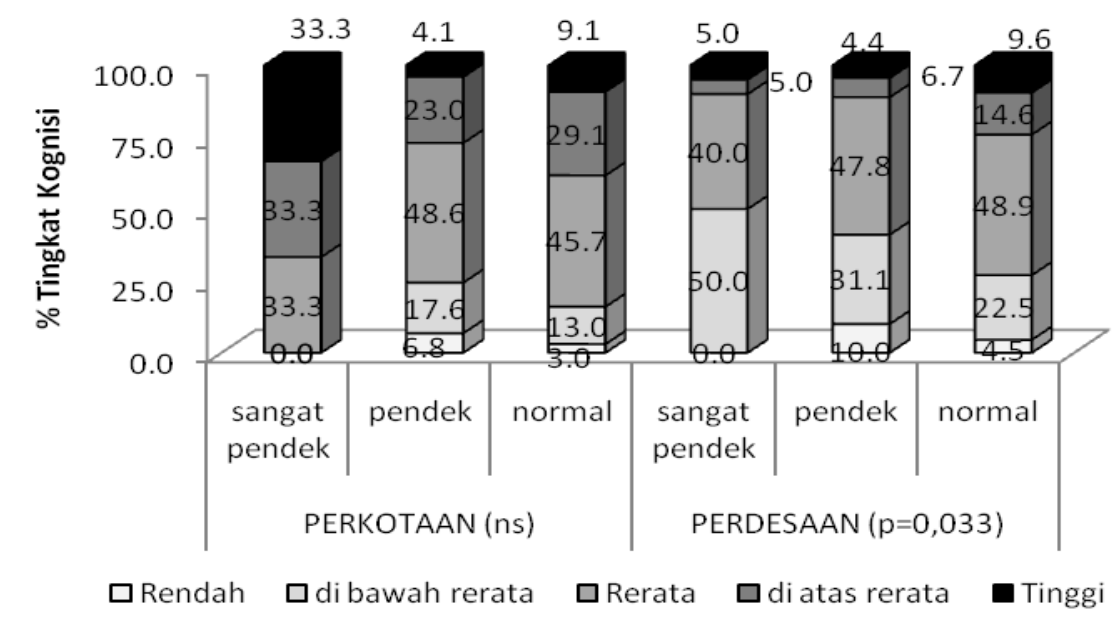

Secara keseluruhan, asosiasi antara kognisi dan postur tubuh tidak tampak jelas pada anak berusia 5-8 tahun. Namun demikian, hubungan itu diduga dipengaruhi oleh lingkungan tempat anak tumbuh terutama stimulasi neuropsikologis.

Gambar 1

Sebaran Proporsi Kognisi Anak Berusia 5,5-7,9 Tahun menurut Postur Tubuh (Z_TBU) yang Pendek dan Sangat Pendek 
Tabel 1

Sebaran Proporsi Kognisi Anak Berusia 5,5-7,9 Tahun menurut Postur Tubuh (ZTBU)

\begin{tabular}{llrrrrrr}
\hline Orbitasi & Postur & $\mathrm{n}=598$ & Rendah & $\begin{array}{l}\text { di bawah } \\
\text { rerata }\end{array}$ & Rerata & $\begin{array}{l}\text { di atas } \\
\text { rerata }\end{array}$ & Tinggi \\
\hline \multirow{2}{*}{$\begin{array}{l}\text { Perkotaan (ns) } \\
\mathrm{n}=307\end{array}$} & Sangat pendek & 3 & 0,0 & 0,0 & 33,3 & 33,3 & 33,3 \\
& Pendek & 74 & 6,8 & 17,6 & 48,6 & 23,0 & 4,1 \\
& Normal & 230 & 3,0 & 13,0 & 45,7 & 29,1 & 9,1 \\
\hline \multirow{2}{*}{$\begin{array}{l}\text { Perdesaan }(\mathrm{p}=0,033) \\
\mathrm{n}=288\end{array}$} & Sangat pendek & 20 & 0,0 & 50,0 & 40,0 & 5,0 & 5,0 \\
& Pendek & 90 & 10,0 & 31,1 & 47,8 & 6,7 & 4,4 \\
& Normal & 178 & 4,5 & 22,5 & 48,9 & 14,6 & 9,6 \\
\hline
\end{tabular}

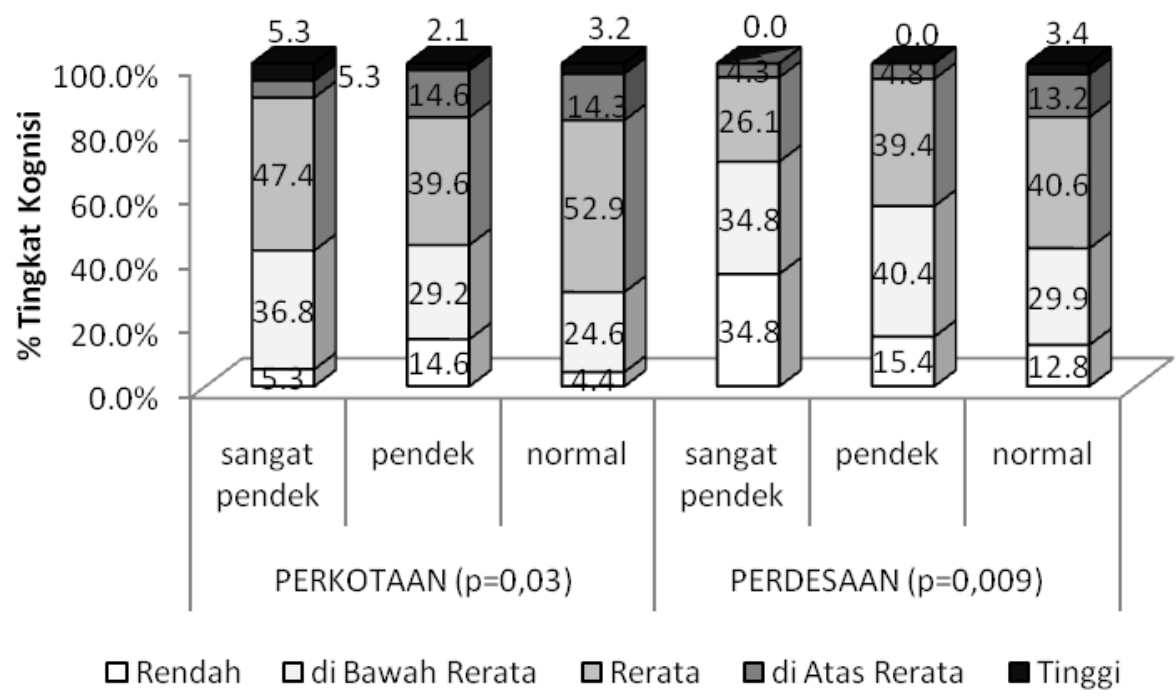

Gambar 2

Sebaran Proporsi Kognisi Anak Berusia 8,0-12,9 Tahun menurut

Postur Tubuh (Z_TBU)

Tabel 2

Sebaran Proporsi Kognisi Anak Berusia 8,0-12,0 Tahun menurut

Postur Tubuh (Z_TBU)

\begin{tabular}{llcccccc}
\hline Orbitasi & \multicolumn{1}{c}{ Postur } & $\mathrm{n}=\mathbf{7 7 3}$ & Rendah & $\begin{array}{l}\text { di bawah } \\
\text { rerata }\end{array}$ & Rerata & $\begin{array}{c}\text { di atas } \\
\text { rerata }\end{array}$ & Tinggi \\
\hline Perkotaan & Sangat pendek & 19 & 5,3 & 36,8 & 47,4 & 5,3 & 5,3 \\
$(\mathrm{p}=0,03)$ & Pendek & 96 & 14,6 & 29,2 & 39,6 & 14,6 & 2,1 \\
$\mathrm{n}=412$ & Normal & 297 & 4,4 & 24,6 & 52,9 & 14,3 & 3,2 \\
\hline Perdesaan & Sangat pendek & 23 & 34,8 & 34,8 & 26,1 & 4,3 & 0,0 \\
$(\mathrm{p}=0,009)$ & Pendek & 104 & 15,4 & 40,4 & 39,4 & 4,8 & 0,0 \\
$\mathrm{n}=361$ & Normal & 234 & 12,8 & 29,9 & 40,6 & 13,2 & 3,4 \\
\hline
\end{tabular}

Pada anak yang berusia lebih tua $(8-12,9$ tahun) perbedaan tingkat kognisi tampak berbeda baik di perdesaan $(p=0,03)$ maupun perkotaan $(p=0,009)$. Pada kelompok ini juga terungkap tingkat kognisi di bawah rerata lebih besar, kecuali pada anak perkotaan yang posturnya normal (Gambar 2 dan Tabel 2). Proporsi tingkat kognisi di bawah rerata tampak 
semakin mengecil pada postur sangat pendek, pendek dan normal. Hal ini terjadi di perkotaan dan perdesaan. Pola ini tampak sama dengan kelompok umur yang lebih muda, besaran masalah kognisi lebih besar pada kelompok anak yang lebih tua.

\section{BAHASAN}

Perkembangan kognisi pada anak usia sekolah perlu dicermati dengan baik. Informasi kognisi pada usia ini menjadi dasar dan sangat penting untuk perbaikan perkembangan selanjutnya. Data yang diperoleh dari SEANUTS ini merupakan gambaran nasional Indonesia, yang menunjukkan perkembangan kognisi anak kurang optimal. Proporsi tingkat kognisi di bawah rerata yang ditemukan sangat besar yaitu antara 30-40 persen anak. Bercermin pada perkembangan kognisi di Negara maju seperti German yang proporsinya sekitar 12,2 persen pada anak usia sekolah, maka perkembangan kognisi anak Indonesia sangat lambat. ${ }^{3}$

Jika dicermati lebih teliti terdapat kecenderungan keterlambatan pada kelompok usia yang lebih tua merupakan akibat kumulatif dari perkembangan kognisi sebelumnya. Bukan tidak mungkin pola asuh anak Indonesia merupakan salah satu kunci yang harus dipelajari sebagai faktor risiko terjadi kelambatan tersebut. Pola perkembangan yang sama dan perbedaan tingkat perkembangan kognisi antara anak perdesaan dan perkotaan tampaknya membuktikan perbedaan stimuli kognisi dan menjurus pada pola asuh.

Beberapa penelitian yang cukup kuat reliabilitas dan validitasnya membuktikan bahwa anemia merupakan salah satu risiko keterlambatan neuropsikologik termasuk kognisi. Data SEANUTS memperlihatkan anemia pada anak di Indonesia sangat tinggi bahkan sejak usia 6 bulan. Oleh karena itu bukan tidak mungkin, bahwa pencapaian tingkat kognisi juga dipengaruhi anemia dan mungkin status gizi lainnya.

Efek status gizi yang relevan dengan perkembangan koginisi adalah defisiensi energi protein yang dimanifestasikan pada pencapaian tinggi badan. Postur pendek secara umum membuktikan terjadinya defisiensi energiprotein yang berkepanjangan (kronis).
Defisiensi energi protein merupakan pintu terjadinya defisiensi zat gizi lainnya terutama zat gizi mikro. Proporsi pendek anak usia sekolah di Indonesia sangat tinggi. Oleh karena itu, bukan tidak mungkin defisiensi energiprotein juga merupakan faktor risiko.

\section{SIMPULAN DAN SARAN}

\section{Simpulan}

Perkembangan kognisi anak usia sekolah di Indonesia belum optimal yang kemungkinan disebabkan oleh pola asuh dan multi defisiensi zat gizi makro maupun zat gizi mikro.

\section{Saran}

Periode usia sekolah adalah masa anak menemukan jatidiri dan berpikir objektif. Proporsi anak Indonesia pada masa ini yang kapasitasnya di bawah rerata sangat besar. Oleh karena itu anak Indonesia perlu diberi keleluasaan mengakses/ mengeksplorasi informasi dan kebebasan mengambil keputusan.

\section{UCAPAN TERIMAKASIH}

Penulis mengucapkan terimakasih kepada FrieslandCampina dan melalui Frisian Flag Indonesia yang mendukung dan mengijinkan menggunakan data untuk tulisan ini. Terimakasih kepada teman peneliti SEANUTS lainnya yang mengijinkan menggunakan data terolah untuk kepentingan penulisan artikel ini.

\section{RUJUKAN}

1. Sandjaja, Budiman- Basuki, HarahapHeryudarini, Soekatri-Moesijanti, ErnawatiFitrah, Widodo- Yekti E, et al. Deasin Penelitian South-East Asia Nutrition Survey (SEANUTS) di Indonesia dan Jumlah Sampel Parameter Anak dan Rumahtangga. Gizi Indonesia. 2013;36(2):75-89.

2. Huitt, W, Hummel, J. (). Piaget's theory of cognitive development. Educational Psychology Interactive. Valdosta, GA: Valdosta State University. Retrieved 3 Juli 2013. Available from http://www.edpsycinteractive.org/topics/cog nition/piaget.html 
3. Stich HL, Baune BT, Caniato RN, Mikolajczyk RT, and Krämer A. Individual development of preschool children prevalences and determinants of delays in Germany: a cross-sectional study in Southern Bavaria. BMC Pediatrics. 2012; 12:188 Retrieved 3 Juli 2013. Available from http://www.biomedcentral.com/14712431/12/188

4. Kawakatsu $Y$, Kaneko S, Karama M and Honda S. Prevalence and risk factors of neurological impairment among children aged 6-9 years: from population based cross sectional study in western Kenya Kawakatsu et al. BMC Pediatrics. 2012; 12:186 Retrieved 3 Juli 2013. Available from http://www.biomedcentral.com/14712431/12/186

5. Szajewska $H$, Ruszczynski $M$ and Chmielewska A. Effects of Iron Supplementation in nonanemic pregnant women, infants and young children on the mental performance and psychomotor development of children: a Systematic review of randomized controlled trials. Am J Clin Nutr. 2010;91:1684-90

6. Sachdev HPS, Gera T, Nestel P. Effect of iron supplementation on physical growth in children: systematic review of randomized controlled trials. Public Health Nutrition. 2006; 9(7): 904-920

7. Lucas A, Morley R, Cole TJ.,Randomised trial of early diet in preterm babies and later intelligence quotient. British Medical Journal. 1998;317:1481-1487

8. Pollit $E$, Saco-Pollit $C$, Jahari $A B$, Husaini $M A$ and Huang J. Effects of an energy and micronutrient supplement on mental development and behavior under natural conditions in undernourished children in Indonesia. Euro J Clin Nutr. 2000;54(Suppl 2): $\$ 80-S 90$

9. Mansur SS, Neto FR. Desvolvimento neuropsicomotor de lectentes desnutridos (neuropsychomotor development of malnourished babies). Revista Brasileira de Fisioterapia. 2006;10(2):185-191

10. Lind $T$, Lonnderthal $B$, Stendlund $H$, et al. A Community base randomized controlled trial of iron and zinc supllementation in Indonesian infants: effects on growth and development. Am J Clin Nutr. 2004:80:72936

11. Dijkhuisezen MA and Wierenga FT. Vitamin A, Iron and Zinc Deficiency in Indonesia. Micronutrient Interaction and Effects of supplementation.Thesis. Wageningen: Wageningen University, 2001.

12. Murray-Kolb LE, Beard JL. Iron treatment normalizes cognitive function in young women. Am J Clin Nutr. 2007;85:778-87

13. Udani PM. Protein energy malnutrition (PEM), brain and various facets of child development. Indian J Pediatr. 1992; 59(2):165-86

14. Santrock JW. Child Development. 11st ed. New York: McGraw Hill, 2007.

15. Sattler, Jerome M. Assessment of Children: Cognitive Applications $4^{\text {th }}$ ed. San Diego: Jerome M. Sattler, Publisher, Inc., 2001.

16. World Health Organization. Growth Reference Data for 5-19 years. Geneve: WHO, 2007. Available from: www.who.int/growth/en/. 